\title{
Dinamika Industri Kopi Bubuk di Lampung (1907-2011)
}

\author{
The Dynamics of Coffee Powder in Lampung (1907-2011)
}

\author{
Oleh Hary Ganjar Budiman \\ Balai Pelestarian Nilai Budaya Bandung \\ Jln. Cinambo No.136 Ujungberung Bandung \\ Email: hgbudiman@gmail.com
}

\begin{abstract}
Abstrak
Penelitian ini berjudul "Dinamika Industri Kopi Bubuk di Lampung (19072011)". Kopi merupakan salah satu sumber daya unggulan di Lampung. Keberadaan industri kopi di Lampung ditopang oleh banyaknya perkebunan rakyat. Metode yang digunakan dalam penelitian ini adalah metode sejarah yang meliputi empat tahap, yaitu heuristik, kritik, interpretasi, dan historiografi. Dalam penelitian ini digunakan konsep industri. Industri adalah kegiatan manufaktur yang di dalamnya terdapat kegiatan produktif yang mengolah bahan mentah menjadi barang setengah jadi atau barang jadi. Awal mula budidaya kopi di Lampung dilatarbelakangi oleh perpindahan penduduk dari Jawa ke Lampung yang telah berlangsung sejak 1905. Para kolonis datang ke Lampung untuk membuka lahan dan menanam berbagai komoditas, salah satunya adalah kopi. Proses perpindahan terus berlangsung dalam beberapa periode; 1905-1941 (Hindia-Belanda) dan pada 1950-1986 (masa kemerdekaan). Selama proses tersebut, pembukaan lahan-lahan perkebunan kopi terus dilakukan di berbagai daerah. Industri kopi bubuk yang pertama berdiri adalah Kopi Njit Sin Hoo (Rajawali) yang sudah ada sejak 1907. Njit Sin Hoo kemudian berganti nama menjadi Kopi Sinar Baru Cap Bola Dunia pada 1950. Industri kopi bubuk berkembang pesat pada 1980 dengan bermunculannya beragam merk kopi bubuk. Memasuki tahun 2007 hingga 2010 dikenal kopi luwak yang memiliki kualitas istimewa dan dikenal di dalam dan luar negeri.
\end{abstract}

Kata kunci: kopi, Lampung, industri kopi bubuk. 


\begin{abstract}
Coffee is one of major resources in Lampung. It is supported by many people's plantations. The author conducted methods in history: heuristic, critique, interpretation, and historiography. The concept that is used in this study is "industry". Industry is manufacture activities involving productivity in processing raw material into halffinished or finished goods. Coffee cultivation in Lampung was motivated by migrations from Jawa to Lampung that took place in 1905. The colonists opened and cultivated land with many commodities, including coffee. There are two phases of migration: during the Dutch colonialism (1905-1941) and after the Independence (1950-1986), and in those periods many coffee plantations were opened in many areas. The first coffee powder industry Njit Sin Hoo (Rajawali) was established in 1907. In 1950 it changed the name into Kopi Sinar Baru Cap Bola Dunia. Coffee industry made its big progress in 1980 along with the introduction of many new brands. By 2007 until 2010 kopi luwak, which has special quality, was introduced.
\end{abstract}

Keywords: coffee, Lampung, coffee powder industry.

\section{A. PENDAHULUAN}

Catatan tertua tentang kopi, pertama kali dikemukakan oleh William Bidulph, seorang berkebangsaan Inggris yang menulis surat dari Allepo pada tahun 1660. Dalam suratnya itu, Bidulph mengemukakan "orang-orang Turki paling sering meminum Coffa, sejenis minuman berwarna hitam, terbuat dari sejenis kacang-kacangan yang disebut Coava, yang dibudidayakan melalui penggilingan, dan dididihkan dalam air panas, mereka meminumnya selagi panas seakan bisa mengakibatkan terluka karena panasnya" (Cowen, 2005: 5). Pada abad ke-16, kopi sudah terdapat di daerah Timur Tengah, Persia, Turki, dan Afrika Utara. Biji kopi pertama kali diekspor dari Ethiopia ke Yaman. Kopi pertama kali dibawa keluar dari Timur Tengah pada 1670 oleh Sufi Baba Budan, dari Yaman ke India. Setelah itu kopi menyebar ke Itali dan seluruh Eropa (Wacana, 2006: 237).

Memasuki abad ke-16 dan ke-17, kopi mulai menjadi komoditi bernilai tinggi di Eropa. Setelah kopi diterima luas di Eropa, Kopi pun secara perlahan menjadi bagian dari imprealisme dan kolonialisme lama, seperti halnya yang dilakukan oleh Vereenigde Oostindische Compagnie (VOC) yang mulai memasuki Indonesia pada pertengahan abad ke-16 dan mulai memperkenalkan kopi. Menurut William H Ukers, disebutkan bahwa VOC merupakan pengimpor kopi pertama dalam skala besar. Setelah mendapatkan komoditas kopi, VOC membudidayakan kopi di Jawa dan Sri Langka pada 1711. Adapun Creutzberg dan van Laane (1987) mengungkapkan keterangan yang berbeda, kopi dibawa ke Hindia Belanda pada 1669, namun bibit kopi pertama ini punah karena kopi yang dikirim terkena bencana banjir di Batavia. Kiriman kopi selanjutnya tiba pada 1699 dan menjadi sumber bagi segala kopi yang tumbuh di Jawa dan di bagianbagian lain kepulauan Nusantara sampai abad ke-21 (Creutzberg dan Van Laanen, 1987: 157).

Kopi menjadi komoditas unggulan di masa VOC dan di masa Hindia Belanda (1800-1942). Pada masa Pemerintahan Hindia Belanda, kopi dibudidayakan di Jawa melalui Preangerstelsel dan Culturstelsel. Memasuki masa Politik Etis, pembudidayaan kopi pun sampai 
Sumatera, salah satunya hingga ke daerah Lampung. Beriringan dengan proses kolonisasi (perpindahan penduduk) tahap pertama (berlangsung dari 1905 sampai 1911) di Lampung, para kolonis asal Jawa dan kolonis keturunan Tionghoa mulai membuka lahan dan mengembangkan tanaman kopi. Tanah Lampung yang subur serta luas memungkinkan pembudidayaan kopi dalam jumlah besar melalui perkebunan rakyat yang tersebar di manamana. Perkebunan ini terus berkembang dari masa pemerintah Hindia-Belanda hingga masa Indonesia merdeka (Creutzberg dan Van Laanen, 1987; Dahlan, 2006; BPS Lampung, 1982-1997; http://www.desamerdeka.com/lintas-desa).

Sajogya (dalam Koentjaraningrat ed., 1984: 394), mengungkapkan bahwa lada dan kopi merupakan tanaman produktif yang awalnya dikembangkan oleh para kolonis dengan cara membuka hutan rimba. Banyaknya kolonis/ transmigran yang datang, bersamaan dengan itu pula banyak perkebunanperkebunan kopi yang dikembangkan. Kondisi ini menciptakan keberlimpahan komoditi kopi di Lampung. Hingga saat ini Lampung menjadi Provinsi pengekspor kopi terbesar di Indonesia, yaitu mencapai $70 \%$ dari keseluruhan eksport kopi seIndonesia (Antara, 10 Januari 2009). Dari titik inilah, kopi di Lampung menjadi kajian yang menarik. Keberlimpahan perkebunan kopi memungkinkan lahirnya industri kopi di Lampung. Adapun industri kopi bubuk di Lampung saat ini menjadi salah satu industri yang berkembang di samping industri kripik. Selain itu, Lampung terkenal dengan Kopi Cap Bola Dunia yang merupakan industri kopi bubuk tertua di Lampung. Faktor semakin populernya kopi luwak Lampung pada periode 2000-an pun menjadi pertimbangan yang menarik untuk mengkaji industri kopi di Lampung.

Berdasarkan latar belakang sejarah dan kondisi kekinian mengenai kopi di Lampung, penulis mengerucutkan permasalahan penelitian pada beberapa poin.
Pertama, bagaimana awal mula kemunculan industri kopi di Lampung. Kedua, bagaimana perkembangannya. Ketiga, bagaimana pengaruh kopi terhadap kehidupan masyarakat, khususnya berkenaan dengan kebiasaan dan pola konsumsi kopi masyarakat Lampung pada umumnya. Adapun untuk memudahkan dalam menyeleksi data dan mengkonstruksi data, penulis menggunakan konsep industri. Industri adalah kegiatan manufaktur (manufacturing) yang di dalamnya terdapat kegiatan yang berupa kegiatan produktif yang mengolah bahan mentah menjadi barang setengah jadi atau barang jadi. Melalui penelitian ini diharapkan dapat mendokumentasikan sejarah industri kopi bubuk di Lampung dan dapat menjadi pijakan awal untuk penelitian lanjutan yang lebih komperhensif.

\section{B. HASIL DAN BAHASAN}

\section{Awal Mula Industri Kopi Bubuk}

Cikal bakal usaha penjualan kopi bubuk di Lampung bisa ditelusuri pada periode pemerintah Hindia-Belanda, atau manakala proses kolonisasi (perpindahan penduduk) dari Jawa ke Lampung mulai dilakukan. Pada tahun 1907 atau dua tahun setelah kolonisasi pertama dilakukan, telah berkembang sebuah usaha kopi kecilkecilan yang dilakukan oleh keluarga keturunan Tionghoa, yaitu keluarga Lee. Usaha kopi tersebut dikelola secara sederhana dengan menggoreng, mengering kan, mengolahnya menjadi kopi bubuk dan menjualnya melalui usahanya sendiri. Usaha berjualan kopi yang dirintis oleh keluarga Lee kemudian diteruskan oleh anaknya yang bernama Lee Yung Hin. Usaha kopi milik Lee Yung Hin sejatinya sudah berdiri sebelum 1907, karena pada tahun 1907 itu usaha kopi milik Lee Yung Hin sudah dikenal oleh masyarakat setempat. Dahulu, kopi yang dijual oleh Lee Yung Hin dikenal dengan nama kopi merk Njit Sin Hoo (Rajawali) (Wawancara dengan Lukas Sukianto, 10 Maret 2012). 
Lee Yung Hin merupakan imigran asal Cina, namun belum bisa dipastikan bagaimana proses dan latar belakang kedatangannya ke Lampung (Wawancara dengan Lukas Sukianto, 10 Maret 2012). Kemungkinan besar awal mula kedatangan nenek moyang Lee Yung Hin sebagai mana umumnya para imigran Cina di masa Hindia Belanda berhubungan dengan dipekerjakannya ia sebagai buruh perkebunan. Orang-orang Tionghoa yang datang ke Lampung merupakan orang-orang yang datang sebelum orang-orang dari Jawa datang dalam proses kolonisasi yang dimulai sejak 1905. Orang-orang Tionghoa memang sangat mungkin datang lebih awal dibandingkan dengan orang-orang Jawa karena orang-orang Tionghoa ini banyak didatangkan ke berbagai daerah sebagai kuli perkebunan. Hal tersebut telah dilakukan sejak VOC memegang hegemoni monopoli perdagangan di Nusantara (Dahlan, 2006: 49).

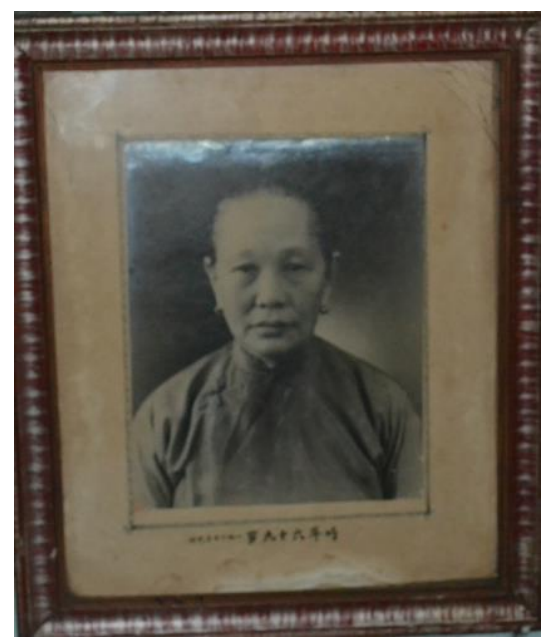

Foto nenek buyut Lukas Sukianto (Keluarga Lee, perintis kopi Njit Sin Hoo ) Sumber: Dokumentasi pribadi

Menurut keterangan Lukas Sukianto cucu dari dari Lee Yung Hin bukti otentik tentang keberadaan usaha dari kakeknya itu masih dapat ditemukan melalui cek-cek berbahasa Belanda yang dibuat pada tahun 1920 dan saat ini masih disimpan oleh ayahnya, bahkan foto nenek buyutnya masih terpajang di toko Sinar Baru Cap Bola Dunia.

Catatan atau bukti sejarah yang lengkap mengenai awal mula dirintisnya usaha kopi oleh keluarga Lee Yung Hin belum bisa direkonstruksi secara utuh, namun dapat diperoleh keterangan dari generasi ke generasi, melalui para penerus usaha kopi tersebut. Lukas Sukianto merupakan generasi keempat yang meneruskan usaha kopi yang dirintis oleh Lee Yung Hin. Menurut keterangan yang disampaikan oleh Lukas yang diketahuinya dari cerita ayahnya usaha kopi yang dijalankan Lee Yung Hin sangatlah sederhana. Sebelum tahun 1950, atau sekitar periode pemerintah Hindia Belanda, Lee Yung Hin masih merintis usahanya dengan berjualan kopi melalui sepeda dan dijajakan dengan cara berkeliling. Kopi yang dijual masih dikemas dengan bungkusan yang sederhana dan disimpan pada sebuah kaleng yang dipasangkan pada sepeda. Saat itu, usaha yang dilakukan Lee Yung Hin belum bisa dikatakan sebagai sebuah industri, namun hanya sebagai usaha perorangan karena bentuk produksi dan penjualannya yang masih sederhana. Usaha yang dilakukan oleh Lee Yung Hin terus berlanjut, dan terus berkembang karena pada tahun 1950 sebuah toko berdiri di Teluk Betung, Bandar Lampung. Toko tersebut dikenal dengan nama Toko Sinar Baru Cap Bola Dunia (Wawancara dengan Lukas Sukianto, 10 Maret 2012).

Lee Yung Hin terus melanjutkan usahanya yang semakin berkembang setelah adanya toko. Pada tahun 1954, anak laki-laki Lee Yung Hin lahir. Anak lak-laki tersebut adalah Sukianto (tidak diketahui nama Tionghoa-nya) yang di kemudian hari melanjutkan usahanya. Pada masa awal-awal kemerdekaan dan masa Revolusi, usaha kopi milik Lee Yung Hin mengalami berbagai liku-liku; mulai dari pengalaman toko yang pernah dirampok hingga menghadapi persoalan sentimen anti-Tionghoa yang sempat marak pada tahun 1966 hingga 1970-an (Wawancara 
dengan Lukas Sukianto, 10 Maret 2012). Pada masa-masa awal berdirinya toko, Lee Yung Hin mengalami berbagai penyesuaian pada pola berjualannya. Misalnya, toko buka pada sekitar pukul 8 pagi, kemudian tutup pada pukul 6 petang, lantas buka kembali pada pukul 7 malam dan tutup pada pukul 10 malam. Pada masa itu, keamanan di sekitar Teluk Betung masih sangat rawan. Suatu kali Lee Yung Hin pernah dirampok di tokonya yang mengakibatkan kakinya terluka karena terkena tembak oleh si perampok. Akibat kejadian tersebut, waktu berjualan pun diperpendek hingga jam 7 malam (Wawancara dengan Lukas Sukianto, 10 Maret 2012). Pada masa awal berdirinya toko Kopi Sinar Baru Cap Bola Dunia memang penuh lika-liku, namun usaha tersebut tidak pernah berhenti, bahkan terus berkembang.

Memasuki tahun 1972, ketika Sukianto sudah beranjak dewasa, usaha kopi milik Lee Yung Hin diserahkan pengelolaannya pada anaknya tersebut. Selama masa manajeman dipegang oleh Sukianto, terjadi berbagai perkembangan penjualan kopi. Biji kopi yang diolah bukan hanya didatangkan dari satu daerah, namun diambil dari berbagai daerah dari perkebunan-perkebunan rakyat yang ada, misalnya dari daerah Tanggamus dan Talang Padang. Pada saat Sukianto mengelola usaha kopi Sinar Baru Cap Bola Dunia, ia sudah mampu memiliki sebuah pabrik yang letaknya berdekatan dengan toko, di Jalan Ikan Kakap-Teluk Betung. Saat itu pula, Sukianto bukan hanya menjual kopi bubuk namun menjual pula berbagai oleh-oleh khas Lampung. Memang ketika itu oleh-oleh khas Lampung sedang melejit ditandai dengan munculnya berbagai toko oleh-oleh seperti toko Yen Yen, Karmel, Manisan Lampung, Manisan Pala, Rumah Kuning, dan lain sebagainya. Adapun beberapa inovasi produk kopi dilakukan oleh Sukianto, di antaranya dengan membuat kemasan kaleng yang berisi antara $2 \mathrm{~kg}$ sampai $9 \mathrm{~kg}$ kopi bubuk. Kemasan bentuk kaleng merupakan sebuah inovasi besar karena kemasan kaleng memerlukan biaya produksi yang tidak sedikit. Kemasan kaleng tersebut sengaja dibuat untuk pesanan-pesanan khusus bagi para pejabat di era Orde Baru, maupun untuk dikirim ke luar negeri (Wawancara dengan Lukas Sukianto, 10 Maret 2012) .

Memasuki tahun 1981, industri kopi bubuk di Lampung mulai semarak. Hal ini terjadi akibat turunnya harga biji kopi di pasar internasional. Industri kopi bubuk, justru mulai muncul ketika harga biji kopi di pasaran turun drastis (Wawancara dengan Bambang, 10 Maret 2012). Secara umum berbagai jenis komoditas ekspor pada tahun 1981 memang mengalami penurunan dalam jumlah komoditas yang diekspor. Pada tahun tersebut kopi nasional hanya mampu diekspor sebesar 100.000 ton, padahal pada tahun sebelumnya mampu mengekspor kopi hingga 126.000 ton. Artinya, terjadi penurunan sebesar 26.000 ton. Adapun turunnya harga kopi di pasaran terjadi karena adanya kelebihan persediaan kopi dunia. Produksi Indonesia tahun 1981 mencapai 270.000 ton. Sementara, kuota untuk International Coffee Organisation berjumlah 138.000 ton. Kelebihan kuota itu harus dipasarkan ke negara-negara non-kuota, seperti negara-negara Eropa Timur dan Timur Tengah. Namun demikian, tetap menjadi permasalahan karena Indonesia mendapat saingan dari Brazil dan beberapa negara Afrika. Negera-negara tersebut bahkan mampu menjual kurang lebih $60 \%$ dari stok nasionalnya (Tempo, 12 Desember 1981).

Bagi para eksportir kopi di Lampung, penumpukan stok kopi jelas merupakan suatu kerugian. Bagi para petani kopi pun hal tersebut membawa dampak yang tidak begitu bagus, di mana harga kopi menjadi menurun dari Rp.1.200 menjadi Rp. 600 per kilo. Meski demikian petani kopi terkena dampak karena jatuhnya harga, tetapi nasib mereka lebih baik, karena sekalipun harga turun, kopi masih memiliki harga jual. Selain itu, kopi 
masih bisa disimpan untuk jangka yang cukup lama (Tempo, 12 Desember 1981).

Turunnya harga kopi di pasar internasional dan daya tahan kopi yang cukup lama, memunculkan insiatif dari para eksportir kopi di Lampung, yaitu dengan membuat biji kopi yang sedianya dieksport ke luar negeri menjadi kopi bubuk. Kopi bubuk ini kemudian dijual pada konsumen lokal (dalam negeri), sehingga kerugian akibat jatuhnya harga kopi di pasaran internasional bisa dicegah. Dari titik itulah, industri kopi rumahan mulai berkembang pesat. Kelebihan dari kopi bubuk yang dijual di dalam negeri adalah harga yang relatif stabil (Wawancara dengan Bambang, 10 Maret 2012).

Harga ekspor biji kopi di tahun 1980 memang mengalami kejatuhan di pasar internasional. Jika biji kopi yang sudah tersedia di tangan eksportir diolah menjadi kopi bubuk untuk konsumsi lokal, maka keuntungan yang diperoleh akan lebih besar dibandingkan dengan diekspor ke luar negeri. Jika diekspor ke luar negeri, untuk proses pengepakan dan pengirimannya akan memakan biaya yang besar, sementara harga biji kopi di luar negeri menurun, tentu hal ini merugikan apabila ekspor tetap dilakukan. Untuk mencegah kerugian dan membuka industri-industri kopi rumahan, para eksportir pun meminta bantuan dana kepada Departemen Perdagangan. Jadi, berkembangnya industri kopi rumahan, terjadi ketika harga biji kopi mengalami penurunan (Wawancara dengan Bambang, 10 Maret 2012). Kondisi demikian bisa dikatakan sebagai peningkatan konsumsi kopi dalam negeri. Keadaan ini pun turut memicu produktivitas perekonomian di Bandar Lampung, maupun perekonomian di keseluruhan Provinsi Lampung.

Maraknya kemunculan industri kopi bubuk rumahan di awal tahun 1981 atau pada pertengahan tahun 1990-an, dapat diperoleh keterangan dari dua perspektif yang berbeda. Pertama, menurut Lukas Sukianto sebagai pengusaha kopi bubuk tertua di Bandar Lampung. Menurut
Lukas, semenjak tahun 1981 mulai bermunculan kopi-kopi bubuk yang sejenis dengan kopi Sinar Baru Cap Bola Dunia. Menurutnya, kopi-kopi yang bermunculan itu banyak di antaranya yang mendompleng merk atau logo dari kopi Sinar Baru Cap Bola Dunia miliknya. Pendomplengan ini dilakukan untuk mendapatkan keuntungan dan ketenaran yang sama dengan kopi Cap Bola Dunia yang sudah sejak dulu berdiri (Wawancara dengan Lukas, 10 Maret 2012). Adapun menurut $R$. Bambang sebagai Kepala Kantor BPD AEKI Lampung dan sudah menggeluti ekspor kopi sejak 1970, memasuki tahun 1980 dan 1981 harga kopi di pasaran internasional mengalami penurunan, sehingga banyak eksportir yang terancam mengalami kerugian. Untuk menanggulangi hal tersebut, banyak di antara eksportir yang kemudian tidak mengekspor biji kopinya, melainkan mengolah biji kopi yang ada menjadi kopi bubuk. Kemudian, kopi bubuk tersebut dijual melalui proses home industry kopi bubuk. Menurut Bambang, di antara eksportir kopi yang ada, banyak juga yang memiliki perusahaan-perusahaan kecil kopi bubuk (Wawancara dengan Bambang, 10 Maret 2012).

Melalui dua keterangan tersebut dapat diketahui bahwa mulai maraknya industri kopi bubuk, terutama industri rumahan di Lampung dimulai sejak tahun 1981, yaitu ketika harga biji kopi di pasar ekspor luar negeri mengalami penurunan. Penurunan tersebut karena penumpukan biji kopi nasional yang tidak terserap oleh pasar internasional. Maka, banyak di antara ekportir yang kemudian mengambil langkah alternatif dengan mengolah biji kopinya menjadi kopi bubuk dan menjualnya pada konsumen lokal, baik di Lampung maupun di Indonesia. Semenjak saat itu, banyak muncul perusahaan dan merk-merk kopi di Lampung yang mengalami pasang surut dalam perjalanan sejarahnya. 


\section{Perkembangan Industri Kopi Bubuk}

Memasuki tahun 1990 hingga tahun 2000 industri kopi bubuk terus berkembang di Lampung. Bermunculan berbagai merk kopi, seperti kopi bubuk cap Anak Jempol, Bola Dunia, Sinar Dunia, JP, JS, JemPol, Siger, JA, Kompas Dunia, Intan Dunia, Tiga Dunia, Just Coffe, dan lain sebagainya. Seperti telah dikemukakan sebelumnya, kemunculan merk-merk kopi baru ini tidak lepas dari kejatuhan harga biji kopi di pasar ekspor internasional pada 1981.

Menurut penelitian yang dilakukan oleh Adang Agustian (2003), dapat diperoleh banyak informasi tentang perkembangan industri kecil kopi bubuk di Lampung. Berdasarkan data Koperindag dan Disbun Lampung tahun 2002, jumlah industri pengolahan kopi bubuk ada dua jenis. Pertama, industri pengolah menengah dan sedang. Kedua, industri skala kecil. Untuk industri yang disebut pertama jumlahnya hanya 8 perusahaan; 6 industri kopi bubuk dan 2 industri kopi instant. Jumlah yang sangat banyak justru terdapat dalam jenis industri skala kecil. Jumlah industri kopi bubuk skala kecil di Lampung pada tahun 2002 mencapai angka 49 perusahaan dengan kapasitas produksi masing-masing perusahaan mencapai 2 hingga 80 ton per tahun. Penyebaran lokasi industri pengolah terbesar terdapat di Kota Bandar Lampung, sedangkan di kabupaten lainnya berkisar antara 14 perusahaan pengolah. Industri pengolahan kopi bubuk di Bandar Lampung ini, hasil produksinya mampu didistribusikan hingga pulau Jawa.

Status usaha industri kopi bubuk skala kecil yang ada di Lampung ini bervariasi, ada yang berupa CV, Usaha Bersama, koperasi dan industri rumah tangga. Pada umumnya perusahaan kopi bubuk yang sudah memiliki kemasan berlabel, biasanya sudah mendaftarkan diri ke Departemen Kehakiman untuk mendapatkan hak paten dari merk yang mereka pakai. Secara umum, memasuki tahun 2000, industri kopi bubuk skala kecil mulai berkembang dan usaha-usaha kecil ini telah memperoleh ijin dari Kantor Dinas Perindag dan dari Departemen Kesehatan. Perkembangan industri kecil ini juga didukung oleh peran aktif pemilik dalam berbagai pameran pertanian (Agustian, 2003: 985).

Demikian pun berkembangnya usaha-usaha kopi bubuk pada tahun 2000, dari sekian banyak merk kopi bubuk itu, bagi sebagian besar konsumen justru menimbulkan kesulitan dalam membedakan antara satu merk kopi dengan merk lainnya, karena banyak di antara merkmerk tersebut yang memiliki logo dan nama yang hampir sama. Menurut keterangan Lukas Sukianto, banyak merk-merk kopi yang nama dan logonya dimiripmiripkan dengan kopi Sinar Baru Cap Bola Dunia atau ada pula yang dimirip-miripkan dengan kopi Cap Jempol. Misalnya ada sebuah merk yang memakai nama "Kompas Dunia", "Piala Dunia", "Cap Sinar Asia", "Cap Bola Asia", "Sinar Asia Bola Asia", "Dunia Baru", "Cap Bintang Dunia", "Cap Tiga Dunia” juga menggunakan logo dan kemasan yang hampir mirip. Pendomplengan logo dan merk ini sudah terjadi sejak tahun 1982 (wawancara dengan Lukas Sukianto, 10 Maret 2012).

Walaupun masih sangat terkesan subjektif, Lukas memaparkan bahwa di Bandar Lampung ini hanya ada dua merk kopi yang memiliki kualitas baik, yaitu kopi Sinar Baru Cap Bola Dunia milik keluarganya dan Kopi Cap Jempol yang menurutnya merupakan salah satu pesaing terberat dalam penjualan kopi bubuk yang telah digelutinya. Kopi Cap Jempol ini merintis usahanya pada tahun 1990-an dengan menjualnya berkeliling menggunakan motor. Memasuki tahun 2000 usaha kopi Cap Jempol semakin berkembang. Kopi Cap Jempol menjual kopi jenis Arabika dan Robusta. Perusahaan kopi yang dimiliki oleh Lukman Hakim ini berusaha menawarkan produk yang ditujukan untuk membidik pasar kalangan bawah yang selama ini cenderung menikmati kopi yang didominasi oleh kopi 
campuran dengan cita rasa yang kurang bagus (wawancara denga Lukas Sukianto, 10 Maret 2012).

Melihat perkembangan industri kopi bubuk yang semakin berkembang dan bertambah banyak, perusahaan Kopi Sinar Baru Cap Bola Dunia bisa menjadi salah satu contoh utuh yang bisa dikaji perkembangan usahanya. Perusahaan Kopi Sinar Baru Cap Bola Dunia memiliki pengalaman yang panjang dalam usaha kopi bubuk di Lampung. Selain itu, perusahaan ini salah satu perusahaan kopi bubuk yang sudah mapan dan dikenal luas oleh banyak konsumen. Dengan melihat perkembangan yang terjadi di Perusahaan Kopi Sinar Baru Cap Bola Dunia, setidaknya dapat diperoleh gambaran pola perkembangan dan produksi kopi bubuk di tengah semakin maraknya merk-merk kopi bubuk sepanjang tahun 1990 hingga tahun 2000-an.

Lukas selaku penerus dan pengelola kopi Sinar Baru Cap Bola Dunia, berusaha melakukan beberapa inovasi agar tetap bisa bersaing dengan merk-merk kopi lain yang semakin banyak. Ada satu hal yang membuat Lukas optimis terhadap usahanya, yaitu pola produksi dan standar kualitas yang terus dipertahankan semenjak kakek dan ayahnya merintis usaha kopi. Awal mula inovasi yang dilakukan Lukas sebetulnya baru dimulai pada tahun 2009. Pada tahun tersebut, Lukas mulai mengambil alih pengelolaan usaha kopi Sinar Baru Cap Bola Dunia. Dibantu oleh adiknya, Willy Sukianto, Lukas melakukan berbagai inovasi. Salah satu inovasi yang cukup signifikan adalah pembuatan kopi kemasan sachet. Sebelumnya, kopi Cap Bola Dunia hanya menjual kopi dengan kemasan kertas yang dibungkus dengan takaran $1 / 4 \mathrm{~kg}$ hingga 1 kg. Memasuki tahun 2011, dibuatlah kemasan sachet dengan isi seberat 8 gram, dan kemasan isi setengah ons dengan harga Rp. 2000,00. Setelah produksi sachet dan kemasan setengah ons berjalan selama 2 hingga 3 bulan, ternyata kemajuannya tidak terlalu mulus karena konsumen cenderung lebih repot dalam penyajiannya. Pada Agustus 2011, kemasan sachet dan setengah ons yang tanpa gula mulai dirombak agar dalam biaya produksi tidak mengalami kerugian, maka kemasan yang tanpa gula tersebut, dibongkar dan ditambahi gula serta ditempeli stiker tambahan dengan tulisan "plus gula".

Pada awalnya satu sachet berisi 8 gram diubah menjadi 23 gram dengan tambahan gula, namun karena terlalu manis, maka komposisi isi kemasan sachet kembali ke 20 gram. Sebelum Lukas memegang dan mengelola usaha, kemasan kopi Cap Bola Dunia masih amat sederhana; dengan bahan kemasan kertas dan logo yang minimalis. Kemasan yang demikian itu, sudah digunakan sejak kakek dari Lukas mengelola usaha kopi. Ketika kopi masih dikelola oleh kakeknya, kopi dijajakan dengan kaleng 9-10 kg. Satu lagi inovasi yang dilakukan Lukas adalah dengan memberi plastik pada kemasan lama. Jadi, kemasan lama tetap dipertahankan namun dengan sedikit pembaharuan. Adapun penambahan plastik dilakukan agar kopi tetap dalam kondisi terjaga manakala konsumen membeli dan membawanya ke luar kota. Dengan pengemasan tersebut, kopi dijual dengan cara yang lebih higienis.

Lukas berusaha berkompromi dengan pasar, yaitu dengan tetap menjaga warna lama dari Kopi Sinar Baru Cap Bola Dunia, namun mencoba memberi sentuhan yang lebih modern dengan adanya kemasan sachet. Kemasan tersebut sekilas memang terlihat seperti halnya kopi-kopi instan yang ada di pasaran, namun Lukas mengakui bahwa cita rasa kopi khas Cap Bola Dunia sama sekali tidak hilang (wawancara denga Lukas Sukianto, 10 Maret 2012). Adapun salah satu keunggulan kopi sachet Cap Bola Dunia dengan kopi sachet merk lain adalah kopi ini dicampur dengan gula murni dan tidak memakai pemanis serta bahan kimia. Sebagian besar kopi kemasan sachet menggunakan esens kopi dan gula yang berasal dari bahan kimia, termasuk pula 
wangi kopi yang dihasilkannya (wawancara dengan Lukas Sukianto, 10 Maret 2012).

\section{a. Produksi}

Pada proses produksi kopi bubuk di Sinar Baru Cap Bola Dunia tidak banyak terjadi perubahan yang berarti. Perusahaan milik keluarga Sukianto ini masih menggunakan tenaga kerja yang relatif sedikit dengan proses pengolahan yang tidaklah terlalu rumit. Petama, biji-biji kopi yang diperoleh dari berbagai perkebunan rakyat di Lampung (Tanggamus dan Talang Padang) kemudian disimpan di gudang kopi yang terletak di Sukaraja. Setelah kopi disimpan di gudang, kemudian biji kopi yang telah masuk ke gudang diambil contohnya dan langsung dicek oleh Bapak Sukianto secara langsung. Uniknya, proses pengecekan yang dilakukan hanya dengan mengambil biji kopi dan dirasakan dengan telapak tangan. Proses pengecekan semacam ini menggambarkan betapa ahli dan hafalnya si pengecek terhadap standar kopi yang diinginkan. Tingkat kekeringan sudah bisa diketahui hanya dengan menggenggam biji kopi yang dicek.

Setelah dicek, kopi disimpan agar lebih kering. Waktu penyimpanan ini beraneka ragam; ada yang satu tahun, dua tahun, bahkan mungkin pula satu bulan tergantung dengan keperluan. Bagi kebanyakan orang, kopi yang disimpan dalam waktu yang lama akan memiliki kualitas yang bagus, namun menurut Lukas, kopi yang ia produksi tidak mengacu pada standar tersebut. Jika memang dalam sebulan atau dua bulan kopi tersebut sudah benar-benar kering, maka biji kopi tersebut akan langsung diolah menjadi kopi bubuk. Biji kopi kemudian digoreng dan diayak agar terhindar dari batu atau benda yang tak layak dikonsumsi. Kemudian, biji kopi dipanggang menggunakan roaster. Salah satu alasan mengapa usaha kopi milik keluarga Sukianto diberi nama Kopi Cap Bola Dunia karena mesin pemanggang kopi yang digunakan bentuknya seperti bola dunia, maka dinamakanlah kopi Sinar Baru Cap Bola Dunia.

Adapun mesin roaster yang digunakan merupakan mesin lama, dengan merk Bhuat. Pernah pula menggunakan mesin Probhat namun kurang cocok terhadap kopi yang diolah dan hasilnya berbeda. Penggunaan bahan bakar mesin pun menggunakan minyak tanah bukan kayu bakar. Perbedaan bahan bakar mesin turut pula dalam mempengaruhi kualitas kopi. Setelah diolah, kopi bubuk dari pabrik dibawa dan baru dikemas ketika sudah sampai di toko, di Jalan Ikan KakapTeluk Betung. Produksi dalam satu hari ditentukan berdasarkan stok, bisa 3 ton, tapi bisa pula dalam sehari sama sekali tidak berproduksi (wawancara dengan Lukas Sukianto, 10 Maret 2012).

Secara umum proses pengolahan kopi bubuk yang dilakukan oleh perusahaan-perusahaan lain di Lampung memiliki pola yang hampir sama dengan yang dilakukan oleh perusahaan Kopi Sinar Baru Cap Bola Dunia. Secara sederhana dapat dijelaskan seperti berikut: pertama, mengumpulkan biji kopi dengan kualitas yang baik maksimum dengan kadar air 20\%. Kemudian, kopi dicuci bersih dan disimpan di suatu tempat, lalu diberi garam untuk mengeluarkan racunnya. Selanjutnya kopi disortir, lalu dijemur sekitar 3 hari untuk memperoleh kadar air maksimum17 \%. Selanjutnya kopi disangrai (di-oven), setelah semuanya gosong merata lalu digiling, dikemas dan selanjutnya dipasarkan kepada konsumen (Agustian, 2003: 986). Demikian proses produksi kopi bubuk secara umum, dalam proses ini tentu memerlukan modal investasi terhadap alat dan bahan produsksi. Dalam tulisannya, Adang Agustian (2003) mengungkapkan data primer tentang modal awal dan investasi alat untuk proses 
Tabel 1

Nilai investasi Mesin dan Peralatan yang Dimiliki Industri Pengolahan Kopi Bubuk

\begin{tabular}{|c|c|c|c|c|}
\hline No & $\begin{array}{c}\text { Jenis } \\
\text { Peralatan/mesin }\end{array}$ & $\begin{array}{l}\text { Jumlah } \\
\text { (unit) }\end{array}$ & Kapasitas alat & $\begin{array}{l}\text { Nilai investasi } \\
\quad(\mathrm{Rp})\end{array}$ \\
\hline 1. & Mesin Kupas & 3 & $\begin{array}{l}\text { a. } 1,2 \text { ton/hari } \\
\text { b. } 7 \mathrm{kw} / \mathrm{hari} \\
\text { c. } 1,5 \text { ton/hari }\end{array}$ & $\begin{array}{l}\text { Rp. 4.000.000 } \\
\text { Rp. } 3.400 .000 \\
\text { Rp. } 1.800 .000\end{array}$ \\
\hline 2. & Mesin giling & 3 & $\begin{array}{ll}\text { a. } & 25 \mathrm{~kg} / \mathrm{jam} \\
\text { b. } & 50 \mathrm{~kg} / \mathrm{jam}\end{array}$ & $\begin{array}{l}\text { Rp. } 750.000 \text { (1 dinamo) } \\
\text { Rp. } 800.000 \\
\text { Rp. } 1.750 .00 \text { ( } 2 \text { dinamo })\end{array}$ \\
\hline 3. & Generator & 1 & 200 watt & Rp. $\quad 850.000$ \\
\hline 4. & Alat packing & 3 & -- & $\begin{array}{ll}\text { Rp. } & 600.000\end{array}$ \\
\hline 5. & Timbangan & 3 & -- & Rp. 390.000 \\
\hline
\end{tabular}

Sumber: Agustian, 2003

Produksi yang dilaksanakan oleh suatu perusahaan skala kecil kopi bubuk di Lampung. Pengusaha kopi bubuk biasanya memerlukan 7 kwintal biji kering untuk diolah atau sekitar 8,4 ton biji kering per tahun untuk menghasilkan 6 ton kopi bubuk. Hitungannya, untuk $1 \mathrm{~kg}$ biji kopi dengan kadar air 20\%, para petani kopi menjualnya sebesar Rp. 3. 200/kg, artinya setiap tahun seorang pengusaha kopi harus mengeluarkan biaya sebesar Rp. 26.880.000.

Adapun pada industri kopi bubuk skala kecil biasanya menggunakan peralatan dan mesin tertentu, seperti mesin kupas, mesin giling, generator, alat packing, dan timbangan. Berikut rincian yang diperoleh dari data lapangan dalam penelitian yang dilakukan Adang Agustian (2003).

Data di atas bisa menjadi gambaran seberapa besar biaya produksi yang diperlukan untuk mengolah biji kopi menjadi kopi bubuk. Hitungan ini berdasarkan pada data primer yang diambil pada 2003, tentu dalam perkembangannya dari tahun ke tahun akan terjadi perubahan, terutama berkenaan dengan bahan utamanya berupa biji kopi.

\section{b. Distribusi}

Distribusi yang dilakukan oleh Kopi Sinar Baru Cap Bola Dunia lebih banyak disebarkan di Lampung. Namun, ada pula pesanan untuk ke Jakarta, Jombang, Semarang, hingga Pekanbaru. Beberapa di antaranya lebih banyak pesanan pribadi. Untuk luar negeri, Kopi Cap Bola Dunia pernah melakukan pameran di Hong Kong, Belanda, dan sekitar Eropa. Bentuk distribusi yang lebih mengikuti perkembangan zaman dan teknologi pun dilakukan oleh Lukas selaku pengelola kopi Cap Bola Dunia. Antara lain melalui account Facebook dengan memanfaatkan segala fasilitas yang ada di Facebook. Dipasarkan pula melalui blog khusus, bahkan dipasarkan melalui forum jual beli yang ada di forum online terkenal seperti kaskus. Selebihnya, selain mendistribusikan ke luar daerah dan melalui 
media online, kopi Sinar Baru Cap Bola Dunia lebih banyak dipasarkan ke supermarket, warung, kios, koperasi atau toko-toko oleh-oleh yang ada di Bandar Lampung dan ke seluruhan Provinsi Lampung. Adapun alur distribusinya dapat dilihat dari bagan berikut.

\section{c. Tenaga Kerja}

Tenaga kerja yang dimiliki oleh kopi Sinar Baru Cap Bola Dunia sebanyak 15 orang; 8 orang berkerja di pabrik, dan 7 orang bekerja di Toko. Dengan tambahan pegawai harian sebanyak 40 sampai 50 orang. Jumlah ini menggambarkan bahwa kopi Cap Bola Dunia masih berupa perusahaan kecil karena jumlah tenaga kerjanya relatif sedikit. Di antara 15 pegawai yang dimiliki oleh perusahaan Kopi Sinar Baru Cap Bola Dunia, sebagian besar merupakan pegawai yang sudah bekerja belasan tahun sejak Bapak Sukianto, ayah dari Lukas Sukianto, masih memegang perusahaan. Bapak Sukianto memiliki kepercayaan yang tinggi terhadap pegawainya sehingga tidak terjadi pergantian yang signifikan. Hal ini bisa terjadi kemungkinan besar karena bentuk perusahaannya yang masih berupa industri kecil atau rumahan, sehingga interaksi antara pemimpin perusahaan dengan pegawai lebih intens terjadi. Kondisi demikian bisa menjadi salah satu gambaran bagi sebagian besar industri kopi tidak banyak terjadi pergantian pegawai, dan kekurangan tenaga pegawai disiasati dengan memanfaatkan tenaga buruh harian.

Banyaknya industri rumahan seperti halnya industri kopi bubuk yang tersebar di Bandar Lampung, menjadi salah satu faktor yang cukup efektif dalam menyerap tenaga kerja. Adang Agustian (2003) mengemukakan bahwa rataan tenaga kerja yang terserap dalam industri kopi bubuk skala kecil mencapai 8 orang sebagai tenaga tetap. Namun, tenaga kerja tersebut tidak setiap hari, tetapi mengikuti jadwal kegiatan pengolahan yang sudah ditentukan dan jadwal kerja wajibnya misalnya ditentukan setiap 2 hari dalam seminggunya (Agustian, 2003: 985)

Dalam data yang dikeluarkan oleh Kanwil Perindustrian Provinsi Lampung terlihat bahwa industri kecil justru lebih mampu menyerap tenaga kerja yang lebih banyak dibandingkan dengan industri besar, seperti yang tercantum dalam tabel berikut ini.

\section{Bagan Alur Distribusi Kopi Bubuk}

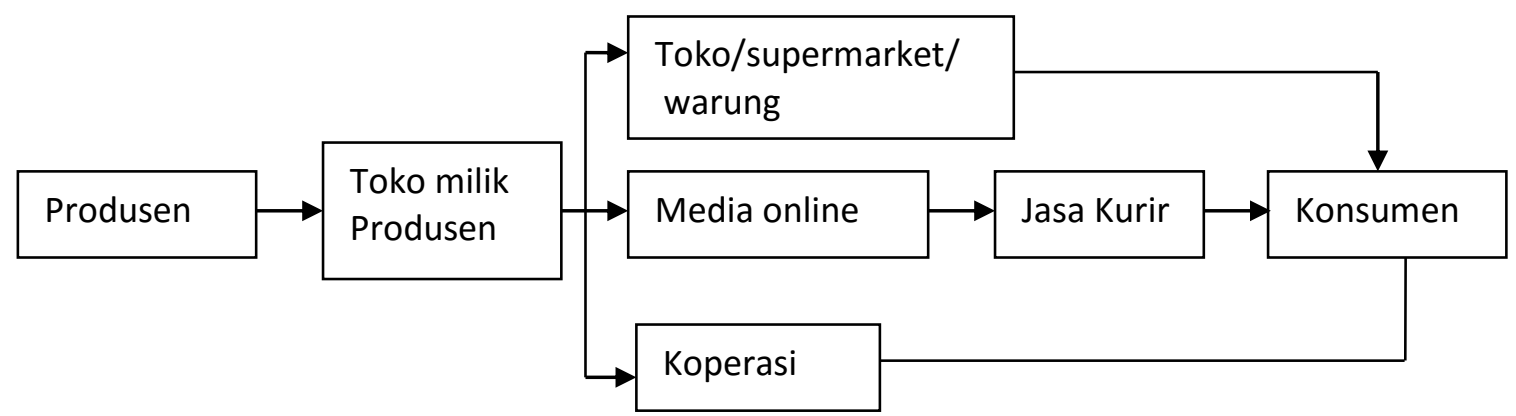

bubuk rumahan di Bandar Lampung, di mana jumlah pegawai tidak terlalu banyak, 
Tabel 2

\section{Jumlah Perusahaan Industri dan Tenaga kerja di Propinsi Lampung 1984-1989}

\begin{tabular}{|c|c|c|c|c|c|c|c|c|}
\hline Tahun & \multicolumn{2}{|c|}{ Industri Besar } & \multicolumn{2}{c|}{$\begin{array}{c}\text { Industri } \\
\text { Sedang }\end{array}$} & \multicolumn{2}{c|}{ Industri Kecil } & \multicolumn{2}{c|}{ Jumlah } \\
\cline { 2 - 9 } & Industri & $\begin{array}{c}\text { Tenaga } \\
\text { kerja }\end{array}$ & Industri & $\begin{array}{c}\text { Tenaga } \\
\text { Kerja }\end{array}$ & Industri & $\begin{array}{c}\text { Tenaga } \\
\text { Kerja }\end{array}$ & Industri & $\begin{array}{c}\text { Tenaga } \\
\text { Kerja }\end{array}$ \\
\hline 1984 & 74 & 10.258 & 141 & 8.398 & 10.067 & $\mathbf{3 5 . 0 6 5}$ & 10.282 & 53.721 \\
\hline 1985 & 74 & 10.258 & 155 & 9.084 & 10.865 & $\mathbf{3 8 . 8 2 4}$ & 11.094 & 58.166 \\
\hline 1986 & 76 & 11.925 & 176 & 8.225 & 12.549 & $\mathbf{4 3 . 7 3 7}$ & 12.801 & 64.877 \\
\hline 1987 & 54 & 11.893 & 229 & 17.196 & 13.398 & $\mathbf{4 6 . 3 0 9}$ & 13.681 & 75.398 \\
\hline 1988 & 59 & 12.745 & 257 & 18.849 & 14.028 & $\mathbf{4 8 . 4 7 5}$ & 14.338 & 80.069 \\
\hline 1989 & 86 & 18.450 & 271 & 19.721 & 15.486 & $\mathbf{5 2 . 7 6 7}$ & 15.853 & 90.938 \\
\hline
\end{tabular}

Sumber: Kanwil Perindustrian Propinsi Lampung, Bappeda Tk.I Lampung (Yusuf, 1992: 87-88 dalam Agustian, 2003).

Angka-angka tenaga kerja yang tercantum di atas, kemungkinan besar didominasi oleh industri yang banyak terdapat di Bandar Lampung. Jumlah industri yang terdapat di Bandar Lampung, jauh meninggalkan jumlah industri yang terdapat di daerah-daerah lain, seperti Lampung Selatan, Metro, Tanggamus, dan lain sebagainya. Data statistik yang dikeluarkan oleh Kantor Perdagangan dan Perindustrian pada tahun 2003 menunjukkan bahwa di Bandar Lampung terdapat 32 perusahaan dengan jumlah produksi mencapai 530,5 ton. Angka ini berbeda jauh dengan kabupaten-kabupaten di Lampung lainnya, yang hanya memiliki 1 sampai 4 perusahaan per kabupatennya (Agustian, 2003: 984).

\section{Kebiasaan Minum Kopi dan Kemunculan Kopi Luwak}

Keberadaan perkebunan kopi dan adanya toko kopi tertua yang sudah terkenal pada 1907 setidaknya bisa memberi sedikit gambaran bahwa masyarakat Lampung boleh jadi sudah mengenal kopi sejak lama, dan tentu saja sudah minum kopi sejak lama pula. Lamanya orang-orang di Lampung mengenal dan mengkonsumsi kopi nampaknya tidak berpengaruh terlalu banyak dalam cara-cara khusus mereka dalam mengkonsumsi kopi. Jejak-jejak kebiasaan minum kopi di Lampung, sejauh pemantauan penulis di lapangan, hanya bisa dilihat dari toko kopi yang sudah ada sejak lama, dan beberapa kedai kopi. Adapun di Bandar Lampung, jumlah kedai kopi itu sendiri tidaklah terlalu banyak. Menurut keterangan Lukas Sukianto, anak pemilik toko kopi Sinar Baru Cap Bola Dunia, di Bandar Lampung ada 3 kedai kopi yang cukup terkemuka dan memiliki banyak pengunjung. Ketiga kedai tersebut adalah Kedai Kopi Sinar Baru dan Kedai Kopi Sinar Baru II (cabang dari Kedai Kopi Sinar Baru). Kedua kedai tersebut terletak di Jalan Kartini, Bandar Lampung. Satu lagi adalah kedai yang bernama Lorong King. Kedai ini hanya buka pada 
pagi hari saja (wawancara dengan Lukas Sukianto, 10 Maret 2012).

Menurut Lukas, hanya ketiga kedai kopi itulah yang layak disebut sebagai sebuah kedai. Besar kemungkinan, bahwa jika pun ada kedai-kedai yang lain, itu kurang memiliki kualitas. Kedai dalam pemahaman ini tentu saja kedai yang benar-benar menyediakan kopi olahan atau biji kopi, bukan sekedar kopi instan seperti halnya warung kopi biasa yang banyak terdapat di jalan-jalan. Kedai yang terdapat di Bandar Lampung ini bisa disejajarkan dengan kedai-kedai kopi yang terdapat di Aceh atau di Medan. Namun demikian, agak berbeda karena jumlah kedai yang ada di Bandar Lampung hanyalah 3 tempat saja.

Menurut keterangan Syamsir Alam, alumni Sejarah Unpad yang lahir di Lampung, masyarakat Lampung bukan masyarakat yang gandrung menikmati kopi. Betul jika dikatakan bahwa daerah Lampung adalah penghasil kopi yang subur, namun secara umum masyarakatnya bukan masyarakat yang memiliki kebiasaan dan budaya yang kuat dalam meminum kopi. Lampung memang memiliki daerah-daerah penghasil kopi seperti: Kota Bumi, Kabupaten Lampung Utara; Kabupaten Tanggamus; Kabupaten Menggala; Kabupaten Krui; Kabupaten Lampung Timur; Metro; atau Kabupaten Lampung Barat. Meski demikian, Lampung berbeda dengan Aceh, Padang, Medan, Riau, atau Palembang. Budaya kumpul-kumpul di warung kopi pada daerah-daerah tersebut tidak lepas dari corak masyrakat lokal daerah setempat yang juga mendapat pengaruh kuat dari orang-orang keturunan India, Cina atau Arab yang sejak jaman dahulu sudah datang di daerah-daerah tersebut. Misalnya, kebiasaan minum kopi di Aceh, Medan, Padang atau Palembang sangat mirip dengan kebiasaan orang-orang Arab, atau India yang biasa minum kopi dengan campuran rempah-rempah. Kebiasaaan seperti itulah yang juga sampai sekarang masih dijalankan oleh masyarakat lokal (wawancara dengan Syamsir Alam, 11 Maret 2012).

Adapun di Lampung, sekalipun penduduknya tidak memiliki kebiasaan minum kopi yang kuat seperti Aceh, Medan, atau Padang, namun adanya kopi dibawa oleh orang-orang keturunan Cina. Seperti yang bisa dilihat dari kopi Sinar Baru Cap Bola Dunia atau dulu dikenal dengan nama Njit Sin Hoo (Rajawali), kopi dibawa dan dikembangkan oleh keluarga Lee Yung Hin sebelum 1907. Ini membuktikan bahwa kebiasaan minum kopi, justru dibawa oleh keturunan asing bukan oleh orang-orang pribumi Lampung.

Jika ditilik secara lebih mendalam, Lampung memiliki masyarakat yang homogen. Kehomogonenan masyarakat Lampung ini didominasi oleh orang-orang dari pulau Jawa yang memang dari zaman kolonial sudah banyak yang bertransmigrasi ke Provinsi Lampung. Dilihat dari karakteristiknya, orang-orang Jawa mempunyai kebiasaan yang berbeda dengan masyarakat Sumatera yang mempunyai kebiasaan berbincang-bincang dan minum kopi di kedai. Orang-orang Jawa adalah pekerja keras jika ditempatkan pada suatu daerah. Hal tersebut kemungkinan tidak lepas karena masyarakat Jawa sudah mempunyai "kebiasaan" untuk bekerja dengan giat karena adanya tanam paksa sejak masa Hindia Belanda di Jawa. Oleh karena itu, kebiasaan minum kopi sulit diidentikkan secara tegas terhadap kebiasaan masyarakat di Lampung. Sementara, yang dimaksud masyarakat Lampung ini pun, justru cenderung didominasi oleh orang Jawa. Adapun masyarakat Lampung asli, atau khususnya para kaum lelaki di Lampung berbeda dengan masyarakat Sumatera yang punya tradisi minum kopi dan berbincang-bincang di kedai. kebiasaan minum kopi pada masyrakat Lampung umumnya lebih sering ditemukan pada acara-acara tertentu seperti pada acara adat, pernikahan, atau acaraacara lainnya (wawancara dengan Syamsir Alam, 11 Maret 2012). 
Masyarakat asli Lampung yang cenderung tertutup membuat kebiasaannya juga berbeda dengan masyarakat lainnya di Sumatera seperti Aceh, Padang, Medan, atau Palembang. Masyarakat Lampung asli pun lebih sedikit jika dibandingkan dengan masyarakat pendatang yang ada di Lampung. Orang-orang asli Lampung juga hanya banyak tinggal pada daerah-daerah pedalaman atau daerah pesisir di Lampung. Kebiasaan minum kopi justru banyak ditemukan di pesisir Bandar Lampung seperti Teluk Betung atau Panjang yang masyarakatnya umumnya bekerja sebagai nelayan yang sering menghabiskan waktu sebelum atau sesudah turun melaut dengan meminum kopi hangat. Kopi yang diminum pun umumnya adalah kopi asli Lampung yang terkenal lebih pahit jika dibandingkan dengan kopi dari daerah lainnya. Biasanya para nelayan di sana lebih suka meminum kopi yang lebih pahit atau dengan campuran gula merah. Para nelayan di Lampung meyakini jika kopi yang dihidangkan lebih pahit atau dengan campuran gula merah lebih dapat memberikan kesegaran, stamina dan energi setelah dan sebelum pergi melaut. Sementara, jika kopi dengan campuran gula putih diyakini mereka justru membuat lemas dan cepat habisnya stamina. Artinya, kebiasaan minum kopi bagi masyarakat pesisir cenderung fungsional, bukan kebiasaan untuk bersantai-santai (wawancara dengan Syamsir dan Tamrin, 11 Maret 2012)

Apabila digeneralisasikan dan dilihat dari kebiasaan konsumsi kopi di Lampung, dapat ditarik suatu hipotesis bahwa masyarakat Lampung asli di pesisir dan pedalaman tidak memiliki kebiasaan yang cukup kuat dalam minum kopi. Minum kopi hanya sekedar minum kopi, bukan membentuk ruang publik di mana segala wacana dan perbincangan muncul di sana, selayaknya yang terjadi di Aceh atau Medan. Kebiasaan minum kopi, boleh jadi hanya berkembang di kalangan tertentu seperti orang-orang keturunan Cina. Hipotesis ini tentu belum begitu kuat, namun setidaknya dapat ditinjau dari kegemaran minum kopi di masyarakat Lampung yang tidak terlalu kuat. Citra kopi yang kuat di Lampung, bukan muncul dari pencitraan akan masyarakatnya yang kuat dalam kebiasaan minum kopi, melainkan citra itu muncul dari daerah Lampung yang banyak menghasilkan kopi. Citra kopi ini semakin menguat justru karena wisatawan luar Lampung yang tertarik membeli kopi khas Lampung. Hipotesis lain bisa dikemukakan berdasarkan masyarakat Lampung yang didominasi oleh orang-orang asli Jawa, yang punya latar belakang sejarah datang ke Lampung justru untuk bekerja keras dan membangun kehidupan baru di daerah transmigrasi. Artinya, kebiasaan bersantaisantai seperti minum kopi tidaklah terlalu tampak.

Kondisi yang dikemukan di atas tentu di masa ini sedang mengalami proses perubahan, setidaknya terhitung sejak 2010 dan 2011 lalu. Pemerintah Lampung, mulai membudayakan dan membiasakan masyarakat untuk minum kopi, seperti yang dikemukakan dalam Lampung Post, Minggu, 23 Januari 2011.

Secara resmi acara minum kopi yang rutin dilakukan para pejabat di Lampung baru sekali sebulan. Nama resminya Coffee Morning Pemerintah Provinsi Lampung. Bergulir dari satu tempat ke tempat lain. Tapi jangan salah, belum tentu kopi yang disediakan di meja peserta, kebanyakan malah air mineral. Staf Ahli Gubernur Bidang Pembangunan Anshori Djausal menjelaskan meski mulai digemari masyarakat, angka konsumsi kopi masyarakat Lampung masih sangat rendah, yakni $0,5 \mathrm{~kg} / \mathrm{kapita} / \mathrm{tahun}$. Bandingkan dengan masyarakat Eropa yang tanahnya tak tumbuh kopi. Angka konsumsinya mencapai $12-14 \mathrm{~kg} / \mathrm{kapita} / \mathrm{tahun}$ (Lampung Post, 23 Januari 2011).

Dari keterangan di atas terlihat adanya upaya Pemerintah Daerah untuk membangun budaya minum kopi di tengah masyarakat Lampung. Memang terlihat agak berbeda, di Lampung meskipun 
menjadi penghasil kopi terbesar, namun masyarakatnya tidak memiliki kebiasaan yang kuat dalam menikmati kopi. Kondisi ini dipertegas oleh pernyataan dari Niko Demos, pemilik café yang bernama The Coffee, di Bandar Lampung. Menurutnya, para pengelola kafe di Bandar Lampung dinilai perlu melakukan gerakan bersama, seperti menggelar satu hari dalam seminggu sebagai hari minum kopi (coffee day). Dengan cara demikian diharapkan akan membangkitkan semangat dalam minum kopi di tengah masyarakat (Lampung Post, 23 Januari 2011). Perlu diketahui pula bahwa di Lampung tidak banyak ditemui café-café yang secara khusus menjajakan kopi khas Lampung. Beberapa café yang terkemuka adalah The Coffee dan Café Kopi Item yang dimiliki oleh Adrizal Sutandar. Namun demikian, ironisnya kopi yang dijual di café-café yang ada di Lampung, justru bukan menawarkan kopi Robusta khas Lampung melainkan kopi Arabika dari daerah lain (Lampung Post, 23 Januari 2011).

Geliat terhadap kopi mulai berkembang kembali di Lampung, semenjak maraknya kopi Luwak ${ }^{1}$. Geliat

$1 \quad$ Awal abad ke-19, sejumlah petani di tanah air, khususnya di Lampung, dipaksa menanam kopi sebagai komoditas andalan. Mereka lalu diwajibkan menyetorkan semua hasil panen kepada Pemerintah kolonial Belanda. Suatu ketika, mereka menemukan sebuah cara untuk menikmati kopi hasil panen tersebut. Cara yang dimaksud adalah dengan mengumpulkan kopi yang jatuh di tanah, termasuk yang berupa kotoran luwak. Kebiasaan ini terus berlangsung hingga ratusan tahun hingga kini, dan dilakukan oleh segelintir petani kopi di Lampung Barat dan Sumatera Selatan. Pengetahuan dan kemampuan untuk mengembangkan kopi luwak, khususnya di Lampung Barat, menurut keterangan Sukardi (ketua kelompok perajin kopi luwak Pesagi Mandiri), baru muncul dan dilakukan setelah datangnya sekelompok wartawan televisi asing dari Hongkong pada tahun 2007. Mereka ini bukan dilihat dari tingginya konsumsi kopi, melainkan geliat masyarakat dalam mengembangkan kopi luwak untuk meningkatkan taraf ekonominya. Seperti umum diketahui, kopi Luwak mulai marak dan dikenal oleh masyarakat. Dalam Kompas tanggal 18 Desember 2010, dikemukakan tentang perkembangan kopi luwak di Lampung. Kopi Luwak bukan hanya didapat dengan pencarian di alam, tetapi kini diproduksi di tempat-tempat pemeliharaan luwak.

Seiring ketenarannya, kopi luwak yang beredar di pasaran kini tidak lagi hanya merupakan hasil pencarian di alam terbuka, seperti di kebun kopi atau hutan. Sebagian besar bahkan dihasilkan dari tempat-tempat pemeliharaan luwak. Di Way Mengaku, Liwa, misalnya, luwak yang terkenal liar dan buas dipelihara di dalam kandang di pekarangan rumah warga. Akan tetapi, yang dipelihara itu hanya yang jenis Paradoxurus dan Arctictis. Musang luwak (Paradoxurus hermaphroditus) tercatat sebagai salah satu hewan yang biasa memakan buah kopi dan menghasilkan kopi terbaik. Hewan ini banyak ditemukan di perkebunan kopi dan hutan di Sumatera dan Jawa (Kompas, 18 Desember 2010).

Selain diproduksi secara khusus di beberapa daerah, kopi luwak pun diinovasikan menjadi minuman yang spesial dan berbeda. Misalnya, dikenal es kopi luwak dan durian kopi luwak yang terkenal di Lampung Barat (Antara, 28 September 2010). Adapun ketenaran kopi luwak, bahkan sampai pada acara TV Show terkemuka di Amerika Serikat, yaitu Oprah Winfrey Show. Menurut Oprah, "Cita rasanya unik dan lezat" (Kompas, 18 Desember 2010).

datang ke Liwa untuk mencari kopi luwak hutan. Setelah itu, barulah Sukardi tahu bahwa kopi luwak ternyata dicari dan harganya mahal, lantas berkembanglah industri-industri rumah tangga kopi luwak di Lampung Barat (Kompas, 18 Desember 2010) 
Keterangan lain dikemukakan oleh Massimo Marcone, peneliti kopi dari Universitas Guelph, Kanada, sebagaimana dipublikasikan dalam jurnal Food Research International. Menurutnya, "pencernaan luwak otomatis menurunkan kadar protein sehingga menghasilkan rasa kopi yang unik dan kaya. Kopi ini karakteristiknya lembut, terkadang berasa cokelat atau karamel. Satu dari kopi terbaik di dunia." Marcone sendiri memfokuskan riset kopi luwaknya di Indonesia. Ketenaran dan kualitas kopi luwak yang bercita rasa tinggi ditegaskan pula dalam majalah Forbes yang menyebutkan bahwa kopi luwak asal Indonesia sebagai kopi termahal di dunia. Dalam sebuah tayangan berita di $\mathrm{CNN}$, secangkir kopi luwak dihargai 100 dollar AS atau hampir Rp 1 juta (Kompas, 18 Desember 2010). Keterangan lain dikemukakan oleh Dewi Ana, seorang eksportir kopi luwak asal Lampung yang telah mengekspor ke berbagai negara. Menurutnya, harga kopi luwak di pasar internasional berkisar Rp 7 juta - Rp 32 juta per $\mathrm{kg}$. Kopi luwak selalu dicari karena langka dan citra kemewahanya. Sebagai perbandingan, biji kopi Hacienda dari Panama dan kopi St. Helena Afrika yang masuk di dalam jajaran kopi papan atas harganya masing-masing $\mathrm{Rp} 1,5$ juta dan $\mathrm{Rp} 1$ juta per $\mathrm{kg}$ (Kompas, 18 Desember 2010).

\section{PENUTUP}

Perusahaan kopi bubuk di Lampung pertama kali dirintis oleh keluarga Lee pada 1907. Awalnya bukan berupa industri yang rumit, melainkan hanya berupa perusahaan perseorangan dengan proses produksi dan distribusi yang dilakukan sendiri. Kopi yang dijual oleh Lee Yung Hin dikenal sebagai kopi Njit Sin Hoo (Rajawali). Usahanya tersebut dijalankan secara turun temurun. Tahun 1950, kopi Njit Sin Hoo berganti nama menjadi Kopi Sinar Baru Cap Bola Dunia dan menempati sebuah toko di Jalan Ikan Kakap, Teluk Betung. Kopi bubuk Sinar Baru Cap Bola
Dunia terus berkembang hingga empat generasi; dikelola oleh Sukianto (19722009), kemudian diteruskan oleh kedua anaknya, Lukas dan Willy Sukianto semenjak tahun 2009.

Pada tahun 1981, harga kopi di pasar internasional menurun sehingga banyak eksportir biji kopi beralih menjadi pengusaha kopi bubuk untuk menghindari kerugian. Sejak saat itu industri kopi bubuk berkembang dan berbagai merk kopi bermunculan di Lampung. Kopi bubuk Sinar Baru Cap Bola Dunia pun mendapatkan banyak pesaing. Untuk mengikuti tuntutan pasar yang semakin ketat, produksi kopi bubuk Sinar Baru Cap Bola Dunia melakukan beragam inovasi, mulai dari proses produksi, distribusi, dan kemasan yang semakin dimutakhirkan. Kemunculan beragam merk dan industri kopi bubuk rumahan di Lampung, turut membantu penyerapan tenaga kerja.

Melimpahnya komoditas kopi di Lampung tidak serta merta membuat masyarakatnya punya kebiasaan kuat dalam menikmati kopi. Citra kopi yang melekat di Lampung, bukan muncul dari kebiasaan yang kuat dalam minum kopi, melainkan citra itu muncul dari daerah Lampung yang banyak menghasilkan kopi. Citra kopi ini justru semakin menguat karena wisatawan luar Lampung yang tertarik membeli kopi khas Lampung. Masyarakat Lampung yang didominasi oleh orang-orang Jawa lebih memfokuskan kebiasaan hidupnya dengan bekerja keras. Lemahnya kebiasaan minum kopi dapat terlihat dari jumlah kedai kopi dan café yang tidak seberapa. Bagi masyarakat asli Lampung - di pedalaman dan pesisirkebiasaan minum kopi pun tidak begitu kuat. Munculnya kebijakan coffee morning dari pemerintah daerah membuktikan masih rendahnya tingkat konsumsi kopi bagi masyarakat Lampung itu sendiri. Adapun dikenalnya kopi luwak di Lampung ternyata tidak mendongkrak konsumsi kopi masyarakatnya, melainkan menumbuhkan geliat produksi kopi luwak untuk menumbuhkan ekonomi masyarakat. 


\section{DAFTAR SUMBER}

1. Buku

Agustian, Adang. 2003.

Daya Saing dan Profil Produk Agroindustri Kopi Skala Kecil (Kajian di Provinsi Lampung). Balai Besar Penelitian dan Perkembangan Pascapanen Pertanian.

BPS Lampung. 1983.

Lampung dalam Angka. 1982-1983.

------. 1986.

Lampung dalam Angka. 1985-1986.

Cowan, Brian. 2005.

The Social Life of Coffee; The Emergence of British Coffehouse. London: Yale University

Creutzberg , Pieter dan J.T.M. van Laanen. 1987.

Sejarah Statistik Ekonomi Indonesia. Jakarta: Yayasan Obor.

Dahlan, Halwi. 2006.

Sejarah dan Perkembangan Transmigrasi di Indonesia; Gedongtataan di Provinsi Lampung. Laporan BPSNT Bandung

2007.

Kabupaten Lampung Selatan; Suatu Tinjauan Sejarah. Laporan BPSNT Bandung

Hutabarat, Budiman. 2004.

Kondisi Pasar Dunia dan Dampaknya terhadap Kinerja Industri Perkopian Nasional.

(Dalam Jurnal Argo Ekonomi, vol 22 no. 2)

Kartodirdjo, Sartono. 1992.

Pengantar Sejarah Indonesia Baru: 1500-1900 dari Emporium sampai Imperium. Jakarta: Gramedia.

Koentjaraningrat. 1984.
Masyarakat Desa di Indonesia. Jakarta: Lembaga Penerbit Fakultas Ekonomi Universitas Indonesia.

Teggia, Gabriella dan Mark Hanusz. 2003. A Cup of Java. Singapura: Equinox.

Ukers, William H. 1922.

"The Introduction of Coffee into Holland". All About Coffee. New York: Tea and Coffee Trade Journal. 12 Februari 2010.

Wacana; Jurnal Ilmu Pengetahuan dan Budaya. Vol 8 no 2, Oktober 2006.

Universitas Indonesia.

Weinberg, Bennett Alan; Bealer, Bonnie K. 2001.

The world of caffeine: the science and culture of the world's most popular drug. New York: Routledge.

\section{Koran dan Majalah}

Antara 10 Januari 2009, "Ekspor Kopi Lampung Hasilkan 586,561 Juta Dolar AS"

Kompas, 18 Desember 2010, "Dulu Dianggap Hama, Kini Jadi Maskot".

Kompas, 18 Desember 2010, “Kopi Luwak, dari Era Tanam Paksa ke "Oprah Winfrey Show".

Lampung Post, 23 Januari 2011, "Coffee Morning', 'Coffee Day', dan Kopi Dangdut”.

Lampung Post, 23 Januari 2011, "Seruput Kopi Lampung".

Tempo, 12 Desember 1981. "Karet Membusuk, Desa Ditinggal".

\section{Internet}

http://www.desamerdeka.com/lintasdesa/wartadesa/2012/06/sejarah- 
desa-tarnsmigran-pertama-di-

lampung/ (diakses 12 Februari 2011)

http://en.wikipedia.org/wiki/Coffe (diakses 21 Maret 2011)

\section{DAFTAR INFORMAN}

1. Lukas Sukianto

Tempat tanggal lahir: Mei 1983

Alamat: Jl. Ikan Kakap No. 36/57.

Teluk Betung - Bandar Lampung

Pekerjaan: Pemilik Perusahaan Kopi

Bubuk Sinar Baru

2. R. Bambang, SP., SE.

Tempat tanggal lahir: Lampung, 19 November 1955

Alamat: Jl. Dewi Sartika no 16. Golakgalik-Teluk Betung Utara

Pekerjaan: Kepala Kantor BPD AEKI

Lampung

3. Syamsir Alam

Tempat tanggal lahir: Bandar Lampung, 23 Juni 1986

Alamat: Jl. Ikan kapasan no.12

Kel.Bumi Waras. Kec. Teluk Betung

Selatan, Bandar Lampung

Pekerjaan: Mahasiswa Unpad jurusan Ilmu Sejarah

4. Tamrin Tamin

Tempat tamggal lahir: Bengkulu, 15 Agustus 1938

Alamat: Jl. Ikan kapasan no.12 kel.Bumi Waras. Kec. Teluk Betung Selatan, Bandar Lampung, Lampung. Pekerjaan: Wakil ketua SPSI Lampung 